\title{
Insurance Industry and Non-Agriculture Sector of Nepal: An Empirical Study
}

\author{
Hom Nath Gaire \\ Deputy Director, Confederation of Nepalese Industries (CNI) \\ Email: gaire_mukunda@hotmail.com
}

\begin{abstract}
In this paper, an attempt has been made to analyze relationship between Nepalese insurance industry and the non-agriculture sector using the annual data of the period of 1997 to 2010. In order to accomplish this goal, unit root test, cointegration test, granger causality test, and ordinary least square method of regression analysis have been performed. The empirical result from the cointegration tests clearly shows that there is a long-run relationship between total premium collection and Resources/Liabilities of Nepalese insurance industry vis-àvis non-agriculture real GDP. Likewise, the null hypotheses that the total premium collection and Resources/Liabilities does not granger cause non-agriculture real GDP of Nepal are rejected. Moreover, estimated coefficients of regression models also indicate that there is strong positive correlation between the insurance industry and non-agriculture sector of Nepal.
\end{abstract}

\section{JEL Classification: G22}

Key Words: Granger Causality, Insurance Industry, Non-Agriculture Real GDP

\section{INTRODUCTION}

Insurance, in law and economics, is one of the risk management tools primarily used to hedge (an activity designed to reduce the risk imposed by other activities) against the risk of a contingent loss. Similarly, insurance is a cooperative device of distributing losses, falling on an individual or his family over a large number of persons, each bearing a nominal expenditure and feeling secure against heavy loss (Mishra, 2009). Thus, insurance is a social device to accumulate funds to meet the uncertain losses arising through a certain risk to a person insured against the risk.

Insurance in its simplest form is familiar to everyone in their personal life in the form of car insurance, buildings and contents household insurance, and life insurance. Each person or household pays a premium to transfer 'catastrophic risks' to an insurance company. The insurer (insurance company) calculates the premiums according to actuarial techniques using statistical data, so that on average the insurer makes a profit, even though it will have to pay out some claims (Farquhar, 2003). The principle is based upon the insurer spreading its risk over different clients, some of them will incur losses and make claims, but most of them will not. In this regard, insurance has been introduced to safeguard the interest of people from uncertainty by providing certainty of payment at a given contingency. 
Insurance appears simultaneously with the appearance of human society (Cragg and Uhler, 1971). There are two types of economies in human societies: first, money (modern) economies with markets, money, financial instruments; and second, non-money (ancient) economies without money, markets, and financial instruments. In the ancient economy, insurance was in the form of people helping each other. For example, if a house burns down, the members of the community help to build a new one. If the same thing happens to one neighbor, the other neighbors must help, otherwise, they will not receive help in the future. Insurance in a money economy, is a part of the financial system, was practiced by Chinese and Babylonian traders as long ago as the third and second millennia BC, respectively as an early methods of transferring or distributing risk (Hong, 2008).

The rest of the paper is organized as follows. The next section briefly presents the insurance and economic development followed by review of Nepalese insurance industry. The following section covers the rational of this study and review of literatures is presented in the next section. The subsequent section discusses on data and methodology, which is followed by another section providing empirical findings and discussion. The last section presents summary, conclusion, and recommendation.

\section{Insurance and Economic Development}

A strong and healthy insurance sector is of utmost importance for all sectors of the economy (Matthews and Murrey, 2007). It enables private households to obtain a higher quality of life by satisfying their desire for security and for a guaranteed income level. Likewise, it promotes entrepreneurial activities in the business sectors. Insurance against premature death or disability in part substitute governmental social spending and safeguards its resources for other essential social purposes. Life insurance, in addition, promotes the financial sector in general and the development of capital market in particular. For the economic growth of the country insurance provides a strong platform to protect against loss of property and system to accumulate adequate capital for investment. Consequently, insurance should not be seen as a luxury, but as a necessary condition for well functioning of any economy (Beatty and Ulrich, 1991).

Insurance companies in another way perform redistribution role as their business is to collect premiums and eventually redistribute that money as payment of the claims and bonus (Robin, 2002). Depending on the type of insurance, redistribution can take place anywhere from a few months to some decades. Because of this time lag between collecting and paying out funds, insurance companies invest their funds to make extra money. Such investment, in one side helps business and government to finance their lucrative projects and in the other side generate profits for the insurance policy owner (in the case of life insurance). Insurance plays three major roles for economic development of the developing countries like Nepal. First, it safeguards the financial health of small and medium sized enterprises. Second, it provides information, which helps companies make a comparison of the risk/return profiles of projects to ensure that the available resources are put to the best possible use. Third, as institutional investors, insurance companies contribute to the development and well-functioning of capital market (Khanal, 2007). From the 
macroeconomic point of view, insurance industry helps to mobilise national savings and narrow down the investment gap of developing economies where domestic savings have not been able to meet the huge funding needs arising from infrastructure projects (Anderson, 1998).

\section{Insurance Industry of Nepal}

Traditionally, Nepalese societies were organized in an agricultural basis and the socioeconomic organizations took care of any problems or calamities confronted to the community. As the development of trade, commerce, and industry took place gradually, necessity of the insurance was felt long ago. But there was no any form of organized insurance in Nepal until 1947 and several brokers of Indian insurance companies were operating there. The first Nepalese insurance company was established in 1947 in the name of "Nepal Malchalani Tatha Beema Company Ltd.", a subsidiary of Nepal Bank Limited, the first commercial bank of Nepal. However, the Indian insurance companies are still conducting business in Nepal through their brokers in Kathmandu and other major cities. By now, there are 25 insurance companies operating under Nepal's Insurance Act, 1992. Out of them 8 are life insurance companies, 16 non-life insurance, and 1 company is dealing with both life and non-life insurance business (Insurance Board, 2007). From ownership perspectives, 3 are fully subsidiary of foreign insurance companies and 3 are joint ventures with foreigners. Similarly, 18 companies are under private ownership, while the government of Nepal owns one company.

If we look at the development of insurance industry in Nepal, there were five insurance companies before 1990. After the political and economic changes in early 1990s, the number of insurance companies has massively increased from 5 to 25 till the date. The total Resources/Liabilities of the insurance industry has also increased almost by 11 folds from Rs. 4.34 billions (3.26\% of non-agriculture GDP) in 1997 to Rs. 47.47 billions (12.36\%) in 2010. At the same time, total premium collection of the insurance industry has increased by almost 14 times from Rs. 1.37 billion in 1997 (1.03\% of non-agriculture GDP) to Rs. 15.26 billions (3.98\%) in 2010. This is the result of liberalization of Nepalese insurance industry to the foreign as well as private insurers and the ever increasing awareness of people towards risks. 
Table: 1 Performance of Insurance Industry (in Percentage)

\begin{tabular}{lrrrrr}
\hline Year & Change in $\mathbf{X}_{\mathbf{1}}$ & Change in $\mathbf{Y}$ & Change in $\mathbf{X}_{\mathbf{2}}$ & $\mathbf{X}_{\mathbf{1}} / \mathbf{Y}$ & $\mathbf{X}_{\mathbf{2}} / \mathbf{Y}$ \\
\hline 1997 & - & - & - & 1.03 & 3.26 \\
1998 & 17.52 & 10.68 & 14.29 & 1.09 & 3.37 \\
1999 & 0.62 & 5.62 & 23.59 & 1.04 & 3.94 \\
2000 & 12.96 & 6.84 & 2.12 & 1.10 & 3.77 \\
2001 & 20.22 & 62.31 & 45.37 & 0.82 & 3.37 \\
2002 & 59.55 & -1.06 & 35.93 & 1.31 & 4.63 \\
2003 & 15.67 & 3.52 & -0.08 & 1.47 & 4.47 \\
2004 & 16.75 & 5.33 & 17.96 & 1.63 & 5.01 \\
2005 & 23.42 & 3.24 & 52.61 & 1.95 & 7.40 \\
2006 & 9.57 & 5.32 & 13.30 & 2.03 & 7.96 \\
2007 & 23.56 & 4.36 & 24.40 & 2.40 & 9.49 \\
2008 & 16.79 & 5.88 & 0.70 & 2.64 & 9.03 \\
2009 & 17.84 & 4.14 & 17.19 & 2.99 & 10.16 \\
2010 & 40.00 & 5.39 & 28.24 & 3.98 & 12.36 \\
\hline Sum & 274.46 & 121.58 & 275.61 & 25.48 & 88.22 \\
Mean & 19.60 & 8.68 & 19.69 & 1.82 & 6.30 \\
SD & 14.60 & 16.12 & 16.40 & 0.91 & 3.02 \\
CV & 74.45 & 185.65 & 83.29 & 50.10 & 47.92 \\
\hline Note: (Source: IBN, & $2009) ; X_{1}=$ Total & premium collection of insurance & industry, & $X_{2}$ & $=$ \\
Resources/Liabilities of insurance industry and $Y=$ Non-agriculture real GDP & & & \\
& & & & &
\end{tabular}

During the review period, the real Gross Domestic Product (GDP) of non-agriculture sector is increased by an annual average rate of $8.68 \%$ with standard deviation (SD) of 16.12 and coefficient of variance (CV) of 185.687, while the total premium collection of the Nepalese insurance industry has registered an average annual growth rate of $19.60 \%$ with the $14.60 \mathrm{SD}$ and $74.45 \mathrm{CV}$. At the same time, total Resources/Liabilities of the insurance industry has increased by an annual average rate of 19.69 with 16.40 and 83.29 values of SD and CV respectively. Likewise, the ratio of total resources/liabilities of insurance industry to non-agriculture real GDP has registered an average value of 6.30 with relatively low SD and CV of 3.02 and 47.92 respectively. Moreover, the ratio of total premium to non-agriculture real has an annual average value of 1.82 with 0.91 SD and CV of 50.10.

\section{Rational of the Study}

As indicated by the statistics above, the insurance industry of Nepal has been getting momentum during the review period. There has been a gradual increase in numbers of insurers (life and non-life), insured people (insurance service buyers), insurance agents, and surveyors. Likewise, the premium collection, resource/liabilities and investment of the insurance industry has been increasing gradually. Similarly, the insurance industry of Nepal has been contributing to raise employment opportunities and the national economy as a whole (IBN, 2009). 
However, there is a gap of research studies that have been done about the development pattern, performance, as well as contribution of insurance industry to the country's economic development. Similarly, very rare empirical studies have been conducted to gauge the relationship and causality between the country's insurance industry and the economic growth. While talking about economic growth, annual growth rate of GDP comes first, which constitutes the two broad sectors, that is, agriculture and non-agriculture. Financial sector is one of the most dynamic components of the country's non-agriculture sector and insurance industry play very important role on it. In this context, the major concern of this study is to find out the casual relationship between the growth/decline of insurance industry and the non-agriculture sector of Nepal. Thus, in this research an attempt was made to come up with the empirical study of relation between insurance industry and nonagriculture sector of Nepal.

The broad objective of this study is, therefore, to find out the relationship between Nepalese insurance industry and the national economy. As an integral part of the financial service sector, insurance industry falls under the broad category of nonagriculture sector of the national economy. The specific objective of this study is to find out the degree and direction of causality between the growth of nonagriculture and insurance sectors of the economy. Another objective is, off course, to forward some recommendations to the government in general and the Insurance Board, the regulator of the country's insurance industry, in particular.

\section{REVIEW OF LITERATURE}

Today, financial sector is one of the most dynamic sectors of any economy and insurance is an important component of financial sector. Growth in insurance products in terms of volume, diversity, and complexity reflects the developing trend in insurance industry and in turn the financial sector of the economy (Gough, 2001). Insurance market activities may contribute to economic growth, both as financial intermediary and provider of risk transfer and indemnification by allowing different risks to be managed more efficiently and by mobilizing domestic savings (Ward and Zurbruegg, 2000). More specifically, insurance can have effects such as promoting financial stability, mobilizing savings, facilitating trade, and commerce, enabling risk to be managed more efficiently, encouraging loss mitigation, fostering efficient capital allocation and also can be a substitute for and complement of government social security programs (Skipper, 2001).

The development of insurance industry including life and non-life insurance, has significant effect to economic growth (Outreville, 1996; Browne and Kim, 1993; Beck and Webb, 2003). Though the acknowledgment of "a sound national insurance and reinsurance market is an essential characteristic of economic growth" by United Nations Conference on Trade and Development (UNCTAD) in 1964 is largely proved by practices, in view of importance of insurance in the economic literature (Li et al., 2007). Likewise, the relationship between resource/liability of insurance industry, premium collection, and economic and financial development was evaluated with cross-section data of 55 developing countries by Outreville (1990) with OLS method. A positive relationship between logarithm of 
resource/liability, premium collection per capita and GDP per capita was found. Potential relationship between growth in insurance industry and economic growth was examined by Ward and Zurbruegg (2000) for OECD countries. Real Gross National Product and total written premium were considered as measures for economic and insurance activity, respectively.

Within the researches on issue about insurance industry and economic growth, total premium collection at country level is usually used to represent insurance activities, thus problem of cointegration seems inevitable. For instances, Ward and Zurbruegg (2000) find no relationship between insurance market size and economic growth for the United Kingdom (UK) with country-by-country aggregated data, while Kugler and Ofoghi (2005) decompose the insurance premium data and find a long run relationship between development in insurance market size and economic growth for most categories of insurance in UK. Third, the difference between relationships of life and non-life insurance to economic growth is not fully understood yet. The characteristics between life and non-life insurance are usually viewed as different (Skipper, 1997; Ward and Zurbruegg, 2000). Outreville (1990) identified links between an economy's economic growth and financial development and resource/liability of insurance industry.

Besides, Beenstock et al. (1986), Truett and Truett (1990), Browne and Kim (1993), Outreville (1996), and Beck and Webb (2003) provided evidences of the positive relationship between life insurance demand and income. However, life and non-life are rarely paired to investigate the difference in their relationship with economic growth. Patrick (1966) identifies two possible patterns in the causal relationship between financial development and economic growth. One is "demand-following" pattern of which the creation of modern financial institutions with their financial assets and liabilities, and related financial services are in response to the demand for these services by investors and savers in the real economy. The other pattern is named as "supply-leading", where the expansion of the financial system precedes the demand for its services. These two kinds of patterns are tested in Kugler and Ofoghi (2005) using aggregated insurance data.

The efficient insurance markets are an essential for the transition countries to achieve integration into the global economy and sustainable as well as strong economic growth (UNDP, 2001). Compared to its importance in Western European countries, the insurance industry was underdeveloped in central and Eastern Europe (Johan, 2007). The insurance was very important to the foundation of the American economy (Herring, 2004). If individuals and businesses could not obtain insurance against various causes of financial misfortune, the American economy would be much less productive and expenditure choices much more constrained (Brian, 2007). Brain presents the most sophisticated and best-informed economic analysis of the key policy issues concerning the insurance industry in the United State. Yet the many aspects of insurance markets remain difficult to explain and provide a rationale for policymakers to revisit the tax and regulatory policies. Economists must thus develop richer models to explain the behavior of insurance markets and its impact on the economy (Johansen, 2008). 
India, one of the most potential emerging insurance markets in the world with immediate premium volume of US $\$ 18$ billion has the prospective to increase to US\$ 90 billion within the next decade (Sinha, 2005). The major drivers include sound economic fundamentals, a rising middle-income class, an improving regulatory framework, and rising risk awareness. This indicates that there strong correlation between economic development and insurance industry in India (Gupta, 2006). Insurance premiums, in India, mostly come from obligatory insurance and the banks were the main clients of insurance agencies, thus it has strong causality with the service sector (Shuhrat, 2006). Singapore's insurance industry, with a steady growth in both gross premiums and underwriting profits, strongly associated with growth of non-agriculture economy (Kwon, 2004). The South Korea's National Health Insurance Act, 1977, provided special financial resources for large businesses, which were the central players in the development of the Korean economy in the 1980s and the 1990s (Cho, 2007). Khanal (2007), explores the relationship and causality between service sector liberalization and financial deepening in Bangladesh, Nepal, and Malaysia.

Most of the literatures related to the development of financial system in general and insurance sector in particular, have identified the causality between insurance industry and economic growth in both the developed as well as developing economies. In this study, national-level annual data of Nepalese insurance industry and non-agriculture real GDP are used, by which relationships between insurance development and economic growth are expected to be tested with less disturbance factors.

\section{DATA AND METHODOLOGY}

This paper is primarily based on the secondary data, which have been collected from the economic survey, an official annual publication of Government of Nepal (GON), Ministry of Finance (MoF) as well as from the Insurance Board of Nepal (IBN), the regulator of the country's insurance industry. To find out the relationship between total premium and Resources/Liabilities of the insurance industry vis-à-vis non-agriculture real GDP of Nepal, the time series annual data for the period of 1997-2010 are used. Because of the lack of required data of the years before 1997, the researcher has been compelled to limit the time horizon of the study. Granger causality test is performed to find out the causality between the given variables. "Granger-causality" implies causality in the prediction sense rather than in a structural sense. It starts with the premise that "the future cannot cause the past", if event A occurs after event B, then A cannot cause B (Granger 1969). Likewise, ordinary least square (OLS) technique is used to perform the regression analysis, which is employed to estimate the contribution of growth of insurance industry to the national economy as indicated by non-agriculture real GDP.

To find out the contribution of insurance industry to the national economy, total premium and Resources/Liabilities of insurance industry are taken as independent variables, and the real GDP of non-agriculture sector is taken as dependent variable. To explain their causality the following models have been developed.

$\mathrm{Y}_{1}=\mathrm{a}_{1}+\mathrm{b}_{1} \mathrm{X}_{1}$ 
$\mathrm{Y}_{2}=\mathrm{a}_{2}+\mathrm{b}_{2} \mathrm{X}_{2}$

Where,

$Y_{1}$ and $Y_{2}=$ non-agriculture real GDP

$X_{1}=$ total premium of the insurance industry

$\mathrm{X}_{2}=$ total resource/liabilities of insurance industry

$a_{1}, a_{2}, b_{1}, b_{2}$ are constant parameters

\section{Unit Root Test}

Many economic and financial time series data exhibit trending behavior or nonstationary in the mean. Leading examples are asset prices, exchange rates, and the levels of macroeconomic aggregates like real GDP. An important econometric task is determining the most appropriate form of the trend in the data (Hamiltan, 1994). If the data are trending, then some form of trend removal is required to transform the data into stationary form prior to analysis. Two common trend removal or detrending procedures are first differencing and time-trend regression. First differencing is appropriate for time series and time-trend regression is appropriate for trend stationary time series.

Unit root tests can be used to determine if trending data should be first differenced or regressed on deterministic functions of time to render the data stationary. Moreover, economic and finance theory often suggests the existence of long-run equilibrium relationships among non stationary time series variables. If these variables are time series, then cointegration techniques can be used to model these long-run relations. Hence, pre-testing for unit roots is often a first step in the cointegration modeling. Since, this study is based on the time series data, it is necessary to check whether a series is stationary or not before using it in a regression. A series is said to be stationary if the mean and auto covariance of the series do not depend on time. Any series whose mean and auto covariance depend on time is said to be non-stationary (Schwert, 1989). The following are the basic features of unit root tests.

Consider a simple autoregressive (AR) 1 process:

$\mathrm{y}_{\mathrm{t}}=\rho \mathrm{y}_{\mathrm{t}-1}+\mathrm{x}_{\mathrm{t}}^{\prime} \delta+\epsilon_{\mathrm{t}}$

Where $x_{t}$ are optional exogenous regressor, which may consist of constant, or a constant and trend, $\rho$ and $\delta$ are parameters to be estimated, and $\epsilon_{\mathrm{t}}$ is assumed to be white noise. If, $|\rho| \geq 1, y$ is a non-stationary series and the variance of $y$ increases with time and approaches infinity. If, $|\rho|<1, y$ is a stationary series. Thus, the hypothesis of stationary can be evaluated by testing whether the absolute value of $p$ is strictly less than one or not. Although, there are different techniques of unit root test, this paper used the Augmented Dickey-Fuller (ADF) test to analyze the data. The ADF test is carried out by subtracting $\mathrm{y}_{\mathrm{t}-1}$ in both side of the equation 3: 
$\Delta \mathrm{y}_{\mathrm{t}}=\alpha \mathrm{y}_{\mathrm{t}-1}+\mathrm{x}_{\mathrm{t}}^{\prime} \delta+\epsilon_{\mathrm{t}}$

Where,

$\alpha=\rho-1$

The null and alternative hypotheses may be written as,

$\mathrm{H}_{0}: \alpha=0$

$\mathrm{H}_{1}: \alpha<0$

And evaluated using the conventional t-ratio for $\alpha$ :

$\mathrm{t}_{\alpha}=\frac{\widehat{\alpha}}{(\operatorname{se}(\widehat{\alpha}))}$

Where,

$\hat{\mathrm{a}}$ Is the estimate of $\alpha$, and $\mathrm{se}(\hat{\mathrm{a}})$ is the coefficient of standard error.

More recently, MacKinnon (1996) implements a much larger set of simulations than those tabulated by Dickey and Fuller (1979). In addition, MacKinnon estimates response surfaces for the simulation results, permitting the calculation of DickeyFuller critical values and $\mathrm{p}$-values for arbitrary sample sizes. The more recent MacKinnon critical value calculations are used by E-Views in constructing test output. The simple Dickey-Fuller unit root test described above is valid only if the series is an auto regressive AR (1) process. If the series is correlated at higher order lags, the assumption of white noise disturbances $\epsilon_{t}$ is violated.

\section{Cointegration Test}

Regression of a non-stationary time series on another non-stationary time series may produce a spurious regression. Engle and Granger (1987) pointed out that a linear combination of two or more non-stationary series may be stationary. If such a stationary linear combination exists, the non-stationary time series are said to be co-integrated. The stationary linear combination is called the co-integrating equation and may be interpreted as a long-run equilibrium relationship among the variables. Economically speaking, two variables will be cointegrated if they have a long-term, or equilibrium relationship between them.

The purpose of the cointegration test is to determine whether the groups of nonstationary series are cointegrated or not. There are number of methods for testing the cointegration. E-Views implements Vector Auto Regression (VAR) based cointegration tests using the methodology developed by Johansen (1992).

Consider a VAR of order $\mathrm{p}$ :

$y_{t}=A_{1} y_{t-1}+\cdots+A_{p} y_{t-p}+B x_{t}+\epsilon_{t}$ 
Where, $y_{t}$ is a k-vector of non-stationary $I(1)$ variables, $x_{t}$ is a d-vector of deterministic variables, and $\epsilon_{\mathrm{t}}$ is a vector of innovations. We may rewrite this VAR as,

$$
\Delta \mathrm{y}_{\mathrm{t}}=\Pi_{\mathrm{t}-1}+\sum_{\mathrm{i}=1}^{\mathrm{p}-1} \Gamma_{\mathrm{i}} \Delta \mathrm{y}_{\mathrm{t}-\mathrm{i}}+\mathrm{Bx}_{\mathrm{t}}+\epsilon_{\mathrm{t}}
$$

Where,

$$
\begin{aligned}
& \Pi=\sum_{i=1}^{p} A_{i}-I \\
& \Gamma_{i}=-\sum_{j=i+1}^{p} A_{j}
\end{aligned}
$$

Granger's theorem asserts that if the coefficient matrix $\Pi$ has reduced rank $r<k$, then there exist $k \times r$ matrices $a$ and $\beta$ each with rank $r$ such that $\Pi=\alpha \beta^{\prime}$ and $\beta^{\prime} y_{t}$ is I (0) r. If the number of co-integrating relations $k$ is the number of exogenous variables and each column of $\beta$ is the co-integrating vector, the elements of $a$ are known as the adjustment parameters in the vector error correction (VEC) model. Johansen proposes two different likelihood ratio tests of the significance of these canonical correlations and thereby the reduced rank of the $\Pi$ matrix: the trace test and maximum Eigen value test, shown in equations (4) and (5) respectively.

$$
\begin{aligned}
& \mathrm{j}_{\text {trace }}=-T \sum_{k=r+1}^{n} \ln \left(1-\lambda_{1}\right) \\
& \mathrm{j}_{\max }=-\mathrm{T} \ln \left(1-\lambda_{1}\right)
\end{aligned}
$$

Here $T$ is the sample size and $\lambda_{\mathrm{i}}$ is the $\mathrm{i}^{\text {th }}$ largest correlation. The trace test tests the null hypothesis of $r$ co-integrating vectors against the alternative hypothesis of $n$ co-integrating vectors. The maximum Eigen value test the null hypothesis of $r$ cointegrating vectors against the alternative hypothesis of $r+1$ co-integrating vectors.

\section{Granger Causality Test}

Correlation does not necessarily imply causality in any meaningful sense of this dynamic word. The econometric graveyard is full of magnificent correlations, which are simply spurious or meaningless. The Granger (1969) approach to the question whether $\mathbf{x}$ causes $\boldsymbol{y}$ is to see how much of the current $\boldsymbol{y}$ can be explained by past values of $y$ and then to see whether adding lagged values of $x$ can improve the explanation. Here, $\mathbf{y}$ is said to be Granger-caused by $\mathbf{x}$ if $\mathbf{x}$ helps in the prediction of $\mathbf{y}$, or equivalently if the coefficients on the several lagged $\mathbf{x}$ are statistically significant. Note that two-way causation is frequently the case; $\mathbf{x}$ Granger causes $\mathbf{y}$ and, $\mathbf{y}$ Granger causes $\boldsymbol{X}$. 
It is important to note that the statement " $\mathrm{x}$ Granger causes $\mathbf{y}$ " does not imply that $\mathbf{y}$ is the effect or the result of $\mathbf{x}$. Granger causality measures precedence and information content but does not by itself indicate causality in the more common use of the term. In general, it is better to use more rather than fewer lags, since the theory is couched in terms of the relevance of all past information. We should pick a lag length 1 that corresponds to reasonable beliefs about the longest time over which one of the variables could help predict the other.

E-Views run regressions of the following form:

$\mathrm{Y}_{\mathrm{t}}=\alpha_{0}+\alpha_{1} \mathrm{Y}_{\mathrm{t}-1}+\cdots+\alpha_{1} \mathrm{Y}_{\mathrm{t}-1}+\beta_{1} \mathrm{X}_{\mathrm{t}-1}+\cdots+\beta_{1} \mathrm{X}_{\mathrm{t}-1}+\varepsilon_{\mathrm{t}}$
$\mathrm{X}_{\mathrm{t}}=\alpha_{0}+\alpha_{1} \mathrm{X}_{\mathrm{t}-1}+\cdots+\alpha_{1} \mathrm{X}_{\mathrm{t}-1}+\beta_{1} \mathrm{Y}_{\mathrm{t}-1}+\cdots+\beta_{1} \mathrm{Y}_{\mathrm{t}-1}+\vartheta_{\mathrm{t}}$

For all possible pairs of $(\mathbf{x}, \mathbf{y})$ series in the group, the reported F-statistics are the statistics for the joint hypothesis:

$\beta_{1}=\beta_{2}=\cdots=\beta_{1}=0$

For each equation, the null hypothesis is that, $\mathbf{x}$ does not Granger-cause $\mathbf{y}$ in the

first regression, and $\mathbf{y}$ do not Granger-cause $\mathbf{x}$ in the second regression. For all these test E-views 5.0 has been used.

\section{FINDINGS AND DISSCUSSION}

Most of previous studies utilized asymptotic methods in the estimation and testing of parameters of the development of insurance industry and the economic growth of the country. Ward and Zurbruegg (2000) use Johansen cointegration trace test and error-correction models and it was concluded that the causal relationships between economic growth and insurance market development may vary across countries. Kugler and Ofoghi (2005) find the components of insurance premium to find a long run relationship between development in insurance market size and economic growth for most components by using Johansen's trace and max cointegration tests. Arena (2008) used the generalized method of moments (GMM) for dynamic models of panel data for 55 countries between 1976 and 2004 to test whether there is a causal relationship between insurance market activity (life and non-life insurance) and economic growth. Robust evidence was found that both life and non-life insurance have a positive and significant causal effect on economic growth. Specifically, for life insurance, high-income countries drive the results, and for non-life insurance, both high-income and developing countries drive the results.

Though these results are important, several aspects of the research on this topic need to be improved. The causal relationships between insurance development and economic growth is still unclear, results from different researches even contradict 
each other. Arestis and Demetriades (1997) and Ward and Zurbruegg (2000) have pointed out that it is important to accommodate the potential for causal relationships to differ in size and direction across countries. They suggest that the role of insurance in the economy may be varied across countries. This could happen when the influence of insurance market development, while channeled through indemnification and financial intermediation, is tempered by country-specific factors.

However, the evidence on the causal relationships between insurance activities and economic growth is scarce on country level. In this study, an attempt have been made to find out the casual relationship between the development of Nepalese insurance industry as indicated by total premium collection and the resource/liabilities vis-à-vis the economic growth of the country as indicated by the non-agriculture real GDP. For this, unit root test, Johansen's trace and max cointegration tests, and Granger causality test, along with the simple regression analysis has been employed. The findings of the analysis and tests were presented in this section.

\section{Empirical Findings}

First of all, ADF test has been performed to examine the unit root in the 3 set of series comprising the total Resources/Liabilities, total premium collection and nonagriculture real GDP (Table 2).

Table 9: Unit Root Tests at level

\begin{tabular}{lrr}
\hline Variable & t-Statistic & Probability \\
\hline LnGDP & -2.6839 & 0.2500 \\
LnTPC & -1.6075 & 0.7641 \\
LnR/L & -2.5324 & 0.2548 \\
\hline
\end{tabular}

Note: Critical values for t-statistics at $5 \%$ for level and first difference are -3.5806 and -3.5875 respectively; $\mathrm{Ln}=$ natural logarithm, GDP = real gross domestic product of non-agriculture sector; TPC $=$ total premium collection; $\mathrm{R} / \mathrm{L}=$ total resources/liabilities of insurance industry.

In the level, the ADF test supports that all 3 series under consideration are stationary. When the data are first differenced, the results for stationary or nonstationary may be different for all series at the $5 \%$ level (Table 3 ).

Table 3: Unit Root Tests at first difference

\begin{tabular}{lrr}
\hline Variable & t-Statistics & Probability \\
\hline$\Delta$ LnGDP & -5.7948 & 0.0003 \\
$\Delta$ LnTPC & -5.1907 & 0.0014 \\
$\Delta$ Ln R/L & -4.5687 & 0.0062 \\
\hline Note: Critical values for t-statistics at $5 \%$ for level and first difference are & -3.5806 and & -3.5875 \\
respectively & &
\end{tabular}

In the unit root test for LnGDP, the null hypothesis that LnGDP is non-stationary is rejected at $5 \%$ level of significance. Similarly, the first difference ADF test supports that the alternative hypothesis of all other series under consideration are stationary. 
The purpose of the cointegration test is to determine whether the groups of series are cointegrated or not, which may be helpful to interpret the long-run equilibrium relationship among the variables. The following table (Table 4) shows the result of cointegration test for the growth of total resource/liabilities and premium collection of Nepalese insurance industry as well as the growth of non-agriculture real GDP of Nepal during the sample period.

\section{Table 4: Result of Co-integration Tests}

Sample (total): 14

Included observations: 13 after adjustments

Trend assumption: Linear deterministic trend

Series: LnGDP, LnTPC, and LnR/L

Lags interval (in first differences): 1 to 1

\section{Unrestricted Co-integration Rank Test (Trace) ${ }^{\text {a }}$}

Hypothesized

Trace

0.05

\begin{tabular}{lrrrr} 
No. of CE(s) & Eigen value & Statistic & Critical Value & Prob.** \\
None * & 0.6869 & 58.8462 & 47.8561 & 0.0033 \\
At most 1 & 0.4072 & 27.4934 & 29.7971 & 0.0901 \\
At most 2 & 0.3666 & 13.3747 & 15.4950 & 0.1018 \\
At most 3 & 0.0380 & 1.0469 & 3.8415 & 0.3062 \\
\hline
\end{tabular}

Unrestricted Co-integration Rank Test (Maximum Eigen Value) ${ }^{\text {b }}$

Hypothesized

No. of CE(s)

None *

At most 1

At most 2

At most 3
Max-Eigen

0.05

NOTE: ${ }^{\mathrm{a}}$ Trace test indicates 1 co-integrating equation (s) at the 0.05 level; ${ }^{\mathrm{b}}$ Max-Eigen value test indicates 1 cointegrating equation (s) at the 0.05 level; * denotes rejection of the hypothesis at the 0.05 level; **MacKinnon-Haug-Michelis (1999) p-values

Table (4) shows the result of cointegration test for the trace statistic and maximum Eigen Value. Unrestricted Cointegration Rank Test (Trace) at $5 \%$ level of significance rejected the null hypothesis that there is no cointegrating equation because the value of calculated t-statistic is greater than critical t-statistic. The trace statistic for the hypothesis having 1, 2, and 3 cointegration equations 27.46, $13.37,1.047$ respectively are less than corresponding critical values $29.79,15.49$, 3.84 thus the alternative hypothesis that there are at most 1,2 , and 3 cointegrating equations is accepted. 
Unrestricted Cointegration Rank Test (Maximum Eigen value) also shows the same result as Unrestricted Cointegration Rank Test (Trace). Hence, according to trace statistics and maximum Eigen Value, total premium and Resources/Liabilities of insurance industry as well as non-agriculture real GDP series are cointegrated.

The result of Granger causality between series under consideration as well as the computed F-values and their respective probability during the period 1997-2010 with specific lag periods are presented in the Table (5). To assess whether the null hypothesis is to be accepted or rejected, a significance level of $5 \%$ is chosen.

\section{Table 5: Result of Granger Causality Test}

Sample: 14, Lag: 1

\begin{tabular}{lrr}
\hline Null Hypothesis: & F-Statistic & Probability \\
\hline LnTPC does not Granger Cause LnGDP & 5.4996 & 0.0273 \\
LnR/L does not Granger Cause LnGDP & 0.5551 & 0.4632 \\
LnGDP does not Granger Cause LnTPC & 8.6867 & 0.0069 \\
LnGDP does not Granger Cause LnR/L & 1.5705 & 0.2217 \\
\hline
\end{tabular}

The Granger causality is found to run between total premium collection and total Resources/Liabilities to non-agriculture real GDP. Thus, the null hypothesis that LnTPC and LnR/L does not Granger Cause LnGDP is rejected at the $5 \%$ level of significance with the given value of F-statistic and probability. Likewise, the null hypothesis that LnGDP does not Granger Cause LnTPC and LnR/L is also rejected at $5 \%$ level of significance, where value of F-statistic is 8.68 and 1.57 with probability 0.01 and 0.22 .

\section{Regression Analysis}

Since, there is cointegration among the data series, it provides the basis for calculation the regression equation. The table below (Table 6) shows the resulting significant regression models.

Table 6: Regression results

\begin{tabular}{|c|c|c|c|c|c|c|c|c|c|}
\hline DV & IV & a-value & b-value & t- stat.* & PR & $\mathbf{R}^{2}$ & $-\mathbf{R}^{2}$ & SE-RL & SE-b \\
\hline GDP & TPC & 170.9784 & 17.7455 & 9.2753 & 0.0000 & 0.9791 & 0.9773 & 43.4383 & 1.9132 \\
\hline GDP & $\mathrm{R} / \mathrm{L}$ & 163.4013 & 5.5255 & 40.4799 & 0.0000 & 0.9984 & 0.9984 & 39.2886 & 0.1365 \\
\hline
\end{tabular}

The result of regression analysis shows that the above regression lines are best fit even at $1 \%$ level of significance. Also R-square value shows the $97-99 \%$ of variation in variables is explained by the regression equations. In these equations intercept coefficients of 170.9784 and 163.4013 have indicated that the nonagriculture real GDP is in comfortable position even in the absence of total premium and Resources/Liabilities of the insurance industry. Likewise, the slope coefficients of regression lines show that a given percent increase in total premium and 
Resources/Liabilities of insurance industry has multiplier effect on the nonagriculture real GDP of the economy. This is due to the multiple roles of insurance companies such as financial intermediaries, risk hedger, income redistributors, and capital market players in the national economy. This has also been indicated by the gradually increasing ratios of total premium to GDP and Resources/Liabilities to GDP.

\section{SUMMARY, CONCLUSION AND RECOMMENDATION}

In this paper, an attempt has been made to analyze relationship between Nepalese insurance industry and the non-agriculture sector using the annual data for the period of 1997 to 2010. In order to accomplish this goal, secondary data of the chosen variables have been collected from the sources of Government of Nepal, Ministry of Finance, and Insurance Board, the regulator of country's insurance industry. From the collected data, unit root test, co-integration test, granger causality test, and ordinary least square method of regression analysis have been performed. Based on the results of these tests and analysis the following conclusions could be drawn.

The null hypothesis that the total premium collection and total Resources/Liabilities of insurance industry of Nepal does not Granger Cause non-agriculture real GDP is rejected. Similarly, estimated results from regression analysis also provide the statistical support for strong long-run relationship between insurance industry and non-agriculture sector of Nepal. The increasing value of the ratios of total premium collection and Resources/Liabilities to non-agriculture real GDP observed in this study clearly reflects the Nepalese insurance sector has gradually come up in the main stream of the national economy.

The main conclusion of this study is that the total premium collection and Resources/Liabilities of insurance industry are co-integrated with the secondary and tertiary sector of the Nepalese economy as represented by the non-agriculture real GDP. This implies that a long-run relationship between the insurance industry and the non-agriculture sector is established. Likewise, this study also reveals that the country's primary or agriculture sector is still deprived from the insurance services. However, the study suggests that still there is a room for in-depth analysis to measure the impact of the insurance industry to the agriculture sector of the economy.

Based on the results of empirical analysis from this paper, it is recommended that the government of Nepal should focus on steady growth of the insurance industry to generate favorable impact on the country's non-agriculture sector, which occupies around $60 \%$ of the GDP, and in turn to boost up country's economic growth. At the same time, the government should focus to make the insurance industry more agriculture-friendly so as to exert the favorable impact of insurance industry on agriculture sector of the country, which employs around two-third of the populations. 


\section{ACKNOWLEDGEMENTS}

The author would like to thank Dr. Navaraj Adhikari (Deputy Director, SEBON) and Mr. Tara Prasad Bhusal (Lecturer of Economics, Patan Multiple Campus) for their encouragement, valuable comments, and suggestions.

\section{REFERENCES}

Anderson. K. 1998, "Capital Markets, Insurance and Investment", University of Vienna, Journal of Economics and Finance-Volume. 28, pp. 523-534

Arena, M., 2008. Does Insurance Market Activity Promote Economic Growth? A Cross-Country Study for Industrialized and Developing Countries. Journal of Risk and Insurance 75, 921-946.

Arestis, P., Demetriades, P., 1997. Financial Development and Economic Growth: Assessing the Evidence. Economic Journal 107, 783-799.

Beatty and Ulrich, 1991, "Re-energizing the Mature Organization, Organizational Dynamics," Volume 20 Issue 1, p.16-30

Beck, T., Webb, I., 2003. Determinants of Life Insurance Consumption across Countries. World Bank Economic Review 17, 51-88.

Beenstock, M., Dickinson,G., Khajuria, S., 1986. The Determinants of Life Premiums: An International Cross-Section Analysis 1970-1981. Insurance Mathematics and Economics 5, 261-270.

Brian. J, 2007, "Edwards Angell Palmer and Dodge Insurance and Reinsurance Update," International Office of Insurance and Reinsurance - USA

Browne, M. J., Kim, K., 1993. An International Analysis of Life Insurance Demand. Journal of Risk and Insurance 60, 671-688.

Cho .S. Y 2007, "The Origin and Implementation of the National Health Insurance Policies in Korea," 1961-1979".

Cragg and Uhler, 1971, "Evolution of insurance," Mc. Graw Hill Book Inc., Singapore, P.261

Dickey, D. and W. Fuller (1979). "Distribution of the Estimators for Autoregressive Time Series with a Unit Root," Journal of the American Statistical Association, 74, 427-431.

Dickey, D., and W. Fuller, 1981, "Likelihood Ratio Tests for Autoregressive Time Series with a Unit Root", Econometrica Volume. 49, pp. 1057-1072.

Engle R. and Granger C., 1987, "Cointegration and Error correction: Representation, Estimation and Testing", Econometrica, Volume. 53, pp. 251-276.

Farquhar .H, 2003, "Insurance Principle and Practice," Mc. Graw Hill Book Inc., Singapore, P.371

Gough T. 2001, "Role of Insurance in Capital Markets and Investment," South Asian Publisher, Delhi, pp. 563-570

Granger C. W. 1969, "Investigating causal relations by econometric models and cross-spectral Methods,"Econometrica 37, 424-438.

Gupta .S. 2006, "How to sustain the steady growth in Indian Insurance Industry," working paper, Insurance Board of India, pp. 37

Hamilton, J. (1994). Time Series Analysis. Princeton University Press, New Jersey.

Herring R. J. 2004, "U.S. Economy, Business and Financial Markets," Journal of Economics and Finance Volume-79, pp 345

Hong M. W. 2008, "China Insurance Sector Analysis," IAIS Issues paper on groupwide solvency Assessment and supervision, IAIS 
IBN. 2009., Different Annual Reports and various issues of "Insurance News and Views", Insurance Board of Nepal, Kathmandu.

Johan M. 2007, "Evolution, Development and Performance of Insurance Industry in Europe," Journal of Economic Dynamics and Control, Volume. 22, pp. 23-54

Johansen S. 2008, "Statistical Analysis of Insurance Industry", Journal of Economic Dynamics and Control, Volume. 12, pp. 231-254

Johansen, S., 1992. Determination of co-integration rank in the presence of a linear trend. Oxford Bulletin of Economics and Statistics 54, 383-397.

Khanal, D.R. (2007), "Banking and insurance services liberalization and development in Bangladesh, Nepal and Malaysia, A comparative study," Asia-Pacific Research and Training Network on Trade Working Paper Series, No 41

Kugler, M., and Ofoghi, R., 2005. Does Insurance Promote Economic Growth? Evidence from the UK. In: Money Macro and Finance Research Group / Money Macro and Finance (MMF) Research Group Conference 2005, 1-3 September, University of Crete, Rethymno, Greece.

Kwon, $\mathrm{H}-\mathrm{j}$, 2004, "Social Influence and Individual Preferences," on Schumpeter"s Theory of Consumer Choice, Review of Social Economy, Taylor and Francis Journals, Volume.52 (4), Pp.301-314

Li, D., Moshirian, F., Nguyen, P., and Wee, T., 2007. The Demand for Life Insurance in OECD Countries. Journal of Risk and Insurance, 74, 637-652.

MacKinnon .R. 1996, "Estimation and Hypothesis Testing of Co-integrating Vectors in Gaussian Vector Autoregressive Models", Econometrica, Volume. 49, pp. 551-580.

Mark, N. C., Ogaki, M., Sul, D., 2005. Dynamic seemingly unrelated cointegrating regession. Review of Economic Studies 72, 797-820.

Matthews .C and Murray .D (2007), "Helping the Bank Customer"s to switch on Insurance," A case Study of Sweden, Journal of Financial Services Marketing, Volume. 11, pp 360-369

Mishra M.N 2009, "Insurance Principles and Practice," sixteenth edition, South Asian Publication, New Delhi

Outreville, J. F., 1990. The Economic Significance of Insurance Markets in Developing Countries. Journal of Risk and Insurance 57, 487-498.

Outreville, J. F., 1996. Life Insurance Markets in Developing Countries. Journal of Risk and Insurance 63, 263-278.

Patrick, H., 1966. Financial Development and Economic Growth in Underdeveloped Countries. Economic Development and Cultural Change 14, 174-189.

Robin P. 2002, "Growth, crisis and change in the insurance industry, "A retrospect, Accounting, Business and Financial History, Volume. 12 Issue 3, p.487-504

Schwert, W. (1989). "Test for Unit Roots: A Monte Carlo Investigation," Journal of Business and Economic Statistics, 7, 147-159.

Shuhrat I. 2006, "Potentials of Insurance Market Development in Allocation of wealth," McGraw Hill Book Company, second edition, P. 187

Sinha T. 2005, "The Indian insurance industry: challenges and prospects," South Asian Publication, New Delhi

Skipper, H. D., 2001. Insurance in the general agreement on trade in services (American Enterprise Institute). 
Skipper, H., Jr., 1997. Foreign Insurers in Emerging Markets: Issues and Concerns, Center for Risk Management and Insurance, Occasional Paper, 97-102.

Truett, D. and Truett, L., 1990. The Demand for Life Insurance in Mexico and the United States: A Comparative Study. Journal of Risk and Insurance 57, 321328.

UNDP, 2001. 'World Human Development Report-2001', UNDP, New York, USA

Ward, D., Zurbruegg, R., 2000. Does Insurance Promote Economic Growth? Evidence from OECD Countries. Journal of Risk and Insurance 67, 489-506. 